\title{
ANALYSIS AND DIFFERENCES IN THE BASIC MOTOR AND SITUATIONAL MOTOR ABILITIES BETWEEN FEMALE HANDBALL PLAYERS IN THE BIH FIRST FEDERAL LEAGUE AND THE FIRST LEAGUE OF THE REPUBLIKA SRPSKA
}

\author{
Srđan Pavlović1, Munir Talović ${ }^{1}$, Elvir Kazazović ${ }^{1}$, and Rasim Lakota ${ }^{1}$ \\ ${ }^{1}$ Faculty of Sport and Physical Education, University of Sarajevo, Bosnia and Herzegovina
}

\section{SUMMARY}

The aim of this study was to confirm the difference in basic motor and situational motor abilities of female handball players. Studies were conducted on 77 adult female handball players playing in the $\mathrm{BiH}$ First Federal League and the First League of the Republika Srpska. For basic-motor abilities, 18 variables were used which covered factors for estimating segmental speed, flexibility, coordination, power, repetitive power and balance. Situational motor capabilities were tested using five hypothetical latent factors which are responsible for situational efficiency in handball: speed of ball handling, precision, throwing strength, speed without the ball, and ball handling.

Discriminative analysis of quantitative differences showed that statistically significant differences exist between the capabilities of players from the BiH First Federal League and the First League of the Republika Srpska. Our results can aid in better understanding, tracking, analyzing and perfecting conditioning and tactical preparation for female handball players at various levels of competition, all in the aim of achieving better quality of competition for senior handball players in BIH.

Key Words: basic motor and situational motor abilities, differences, handball.

\section{INTRODUCTION}

Modern handball is exceptionally quick and explosive and is made up of varying physically intense movements which require high level motor skills, both basic and specific (Czerwinski, 1995; Đug, 2005).

Basic motor abilities form the basis for further development of specific motor abilities which are directly responsible for achieving quality results (Brčić, Viskić Štalec, \& Jaklinović Fressl, 1997; Demir, 2000). The existence of five latent situational motor dimensions in handball has been confirmed by various authors and they are as follows: accuracy, ball handling, speed of movement with the ball, speed of movement without ball and throwing strength.

Kules and Simenc (1983) researched the impact of basic motor abilities on the success of players in handball, and they found that explosive strength (both horizontal and vertical leaping ability and the type of throw), accuracy, speed of movement (with and without the ball) and coordination define the quality of the player.

Handball is increasingly dominated by action and reaction speed, strength, and aggresiveness, as well as the versatility of the player as reflected by how many different positions he/she can play (Delija, Šimenc, \& Vuleta, 1995; Rogulj, 2000; Srhoj, Rogulj, Padovan, \& Katić, 2001; Vuleta, Milanović, \& Sertić, 2003).

Players are required to improve their ability to perform elements of technique with maximum intensity and develop their agility and explosive-reactive movement both in offense and defense

Due to the number of powerful shots, attacks on goal, taxing duels between players, and leaps in defence and offense, players consume large amounts of energy during the game. As such, a handball game 
demands much energy (Mujezinović, 2008; Vuleta, Milanović, \& Sertić, 1999).

The aim of this study is to determine the differences and magnitude of differences at different levels of competition based on basic motor and situational motor indicators.

\section{METHODS}

\section{Sample of entities}

Studies were conducted on 77 physically fit, adult female handball players. All were players from the BiH First Federal League and the First League of the Republika Srpska, who were registered with the $\mathrm{BiH}$ Handball Federation. Definition of motor model in this study was done in accordance with Kurelic et al (1975).

\section{Simple of variables}

To measure basic motor abilites, we used 18 variables. To measure situational motor capabilites we used five variables.

Variables for determining basic motor capablities:

- Hand tapping - MSBTAP,

- Leg tapping - MSBTAN,

- Bend, body twist, touch - MSBPZD,

- Flex movement with a stick - MFLISK,

- Full extensions on a benchs - MFDPK,

- Splits-MFSPA,

- Standing on one leg crosswise on a bench with eyes closed - MRRAV,
- Standing on a turned bench - MRSOK,

- Balancing on a narrow beam-MRSUK,

- Back extensions - MRSIST,

- 30 second sit ups - MRSD30,

- Push-ups - MRSSK,

- Coordination with pole-MKKOP,

- Slalom with three medicine balls - MKS3M,

- 20 steps with pole - MK2IP,

- Long jump from stationary position - MESDM;

- Throwing a medicine ball from a lying position - MFEBML,

- Vertical leap - MESVS.

Variables for determining situational motor capabilities:

- Ball handling in a slalom - SMVLS,

- Shooting at a target - SMGLC,

- Shooting at a distance from a walk - SMSLD,

- Running in a triangle in a basic defensive position - SMTTOS,

- Shooting against a wall for 20 seconds - SMSZ20.

\section{Statistical analysis}

Differences between the BiH First Federal League and the First League of the Republika Srpska players, for each applied variable, were confirmed by a discriminative analysis.

\section{RESULTS AND DISCUSSION}

We analyzed discriminate differences between basic-motor and situational-motor abilities of handball players from First federal league of $\mathrm{BH}$ and First League of the Republika Srpska.

\section{TABLE 1}

Box test results.

\begin{tabular}{lrr}
\hline Box's M & 530.977 \\
\hline F & Approx. & 1.286 \\
\cline { 2 - 3 } & $d f 1$ & 276.000 \\
\hline$d f 2$ & 16520.816 \\
\hline$p$ & .001 \\
\hline
\end{tabular}

Legend: $d f$ - Degrees of freedom; $p$ - Probability.

TABLE 2

The significance results of a discriminant analysis.

\begin{tabular}{cccccccc}
\hline Eigenvalue & $\%$ of variance & Cumulative $\%$ & $R$ & $\lambda$ & $\chi^{2}$ & $d f$ & $p$ \\
\hline 2.753 & 100.0 & 100.0 & .856 & .266 & 83.976 & 23 & .000 \\
\hline
\end{tabular}

Legend: $R$ - Canonical correlation; $\lambda$ - Wilks' Lambda; $\chi^{2}$ - Chi-square; $d f$ - Degrees of freedom; $p$ - Probability. 
TABLE 3

Matrix of the structure of discriminant function.

\begin{tabular}{lc}
\hline & Function \\
\hline MRSIST & .346 \\
\hline SMGLC & -.277 \\
\hline MK2IP & -.222 \\
\hline MFDPK & -.185 \\
\hline MKS3M & .180 \\
\hline SMTTOS & -.169 \\
\hline MRSD30 & .160 \\
\hline SMVLS & .141 \\
\hline MFLISK & -.140 \\
\hline ŠMLŠD & .129 \\
\hline MKKOP & -.127 \\
\hline MFEBML & .127 \\
\hline MRSUK & -.120 \\
\hline MRSOK & -.118 \\
\hline MRRAV & -.095 \\
\hline MRSSK & .091 \\
\hline MESSVS & .067 \\
\hline SMŠZ20 & .062 \\
\hline MSBTAP & .058 \\
\hline MSBTAN & .044 \\
\hline MSBPZD & .019 \\
\hline MESDM & .014 \\
\hline MFSPA & -.007 \\
\hline
\end{tabular}

Legend: MSBTAP - Hand tapping; MSBTAN - Leg tapping; MSBPZD - Bend, body twist, touch; MFLISK - Flex movement with a stick; MFDPK - Full extensions on a benchs; MFSPA - Splits; MRRAV - Standing on one leg crosswise on a bench with eyes closed; MRSOK - Standing on a turned bench; MRSUK - Balancing on a narrow beam; MRSIST - Back extensions; MRSD30 - 30 second sit ups; MRSSK - Push-ups; MKKOP - Coordination with pole; MKS3M - Slalom with three medicine balls; MK2IP - 20 steps with pole; MESDM - Long jump from stationary position; MFEBML - Throwing a medicine ball from a lying position; MESVS - Vertical leap; SMVLS - Ball handling in a slalom; SMGLC - Shooting at a target; SMSLD - Shooting at a distance from a walk; SMTTOS - Running in a triangle in a basic defensive position; SMSZ20 - Shooting against a wall for 20 seconds.

In Table 1 was tested covariance matrix of similarity between two sub-samples (Rađo \& Wolf, 2002) between respondents from First federal league and First League of the Republika Srpska. We can notice that difference of covariance matrix statistically significant $(p=.001)$ and allows access to the further procedure of discriminant analysis.

Analyzing the Table 2 we can see that in this area there was a quantitative difference in the patients, which was expected. We see that there is a formation of an important discriminant function of height.856, which shows us where the correlation data set on which we done a discriminant analysis with discriminant function.

Based on the results of the structure of discriminant functions in Table 3, it can be seen that the highest correlations with the discriminant function, with a variable that maximizes the value of the results of different basic-motor and situational-motor abilities of the two sub-samples have the following variables: 
- Back extensions who are perishing space repetitive strength. A significant contribution to the repetitive force for the front part of the body can be explained by the fact that the strength of the muscle groups except for the body in the crease and kicking feinting, is important for stabilizing hull indispensable in solid contact with the opponent, but this muscle group participates in the folding of the upper leg, which indirectly contributes to the efficiency and speed of the players and without the ball.

- Shooting at a target area is accuracy, and precision is like a specific motor ability has a large share of the final result of which is manifested through the ability of matching stationary targets (goals) for the most movement, but also from a static position.

- 20 steps with pole that belongs to the area of coordination, belonging to the area to assess the factors that coordination to a single, highly complex motor dimension, and we can say that this is a form of motor intelligence in athletes thinking about the movement in time and space, the way his performance, speed of execution and speed of learning new motor actions.

\section{TABLE 4}

Group centroids.

\begin{tabular}{cc}
\hline Group & Function \\
\hline 1 & -1.747 \\
\hline 2 & 1.534 \\
\hline
\end{tabular}

Analysis of the results in Table 4 it can be seen that the first group of respondents, handball players from First federal league $\mathrm{BiH}$ located in the negative part of the discriminant function which is defined variables that have a negative impact on the discriminant function. Second group of respondents are handball players from First League of the Republika Srpska which are located in the positive part of the discriminant function, which define variables that have a positive impact on the discriminant function

\section{CONCLUSION}

Results of this study show that female handball players in different levels of competition differ significantly statistically in basic and situational motor abilities.

The existence of these differences between female handball players of different levels of competition is primarily due to the differences in level of competition. BiH First Federal League players have significantly more motivation because they have better help and support from RSBiH, and therefore have seriously defined careers. As is recognized, the psychological aspect is very important in sport. The second reason for the existence of these differences can be attributed to the training regime. A third reason for the difference is in the level of mental, physical and technical tactical training. The obtained results can contribute to better understanding, tracking and analyzing and perfecting conditioning and tactical training in various levels of competition, with the aim of improving the quality of competition in Bosnia and Herzegovina.

\section{REFERENCES}

Brčić, B., Viskić Štalec, N., \& Jaklinović Fressl, Ž. (1997). Prediktivna vrijednost varijabli za procjenu tehničko-taktičkih elemenata u rukometu [Predictive value of variables for the evaluation of technical-tactical elements in handball]. Kinesiology, 1(29), 60-70.

Czerwinski, J. (1995.). The influence of technical abilities of players on the tactical selection in the handball game. European Handball, 2, 16-19.

Delija, K., Šimenc, Z., \& Vuleta, D. (1995). Razlike u nekim općim i situacijskim testovima motoričkih sposobnosti rukometaša i onih koji ne igraju rukomet Differences in some general and situation tests of motor abilities in handball player and those not play handball]. Kinesiology, 27(1), 57-61.

Demir, M. (2000). Kanonički odnos morfoloskkib dimenzija $i$ situacijsko-motion sposobnosti s mladim rukometašma [Canonic relation between morphological dimensions and situationalmotion abilities with young handball players]. Unpublished master's thesis, University of Sarajevo, Faculty of Sport and Physical Education.

Đug, M. (2005). Efikasnost različitih metoda za poboljsanje sakakačkih sposobnost rukometaša [Efficiency of different methods for improvement of handball players jumping 
ability]. Unpublished master's thesis, University of Tuzla, Faculty of physical education and sport.

Kuleš, B., \& Šimenc, Z. (1983). Odnos između različitih motoričkih sposobnosti i efikasnosti u rukometu [Relationship between different motor abilities and efficiency in handball]. Kinesiology, 15(2), 153-163.

Kurelić, N., Momirović, K., Stojanović, M., Šturm, J., Radojević, Đ, \& Viskić-Štalec, N. (1975). Struktura $i$ avluacija morfoloških i motornih dimenzije omladine [The Structure and evolution of morphological and motor dimensions of youth]. Belgrade, RS: Instititu za naučna istraživanja Fakulteta fizičke kulture.

Mujezinović, M. (2008). Uticaj programiranog treninga na specijalne i bazične motoricke sposobnosti u rukometu Effects of programmed training on special and basic motor abilities in handball]. Unpublished master's thesis, University of Sarajevo, Faculty of Sport and Physical Education.

Rađo, I., \& Wolf, B. (2002) Metode kvantifikacije u sportu [Methods for quantification in sport]. Sarajevo, BA: Faculty of Sport and Physical culture.
Rogulj, N. (2000). Razlike u rukometnim situacionim indikatorima u odnosu na postignute rezultate takmičarskih ekipa na Svetskom prvenstvu 1999 u Egiptu [Differences in situation-related indicators of the handball game in relation to the achieved competitive results of teams at 1999 World Championship in Egypt]. Kinesiology, 32(2), 63-74.

Srhoj,V., Rogulj, N. Padovan, M., \& Katić R. (2001). Influence of the attack end conduction on match result in handball. Collegium antropologicum, 25(2), 611-617.

Vuleta, D., Milanović, D., \& Sertić, H. (1999). Latentna struktura prostornih, faznih, pozicijskih i kretnih karakteristika rukometne igre [Latent structure of the spatial, phasic, positional and movement characteristics of the handball game]. Kinesiology, 31(1), 37-53.

Vuleta, D., Milanović, D., \& Sertić, H. (2003). Odnosi između varijabli šuta na gol i rezultata na utakmicama muškog Europskog rukometnog prvenstva 2000 [Relations among variables of shooting for a goal and outcomes of the 2000 Men's European Handball Championship matches]. Kinesiology, 35(2), 168-183.

Received: October 21, 2013 Revision received: November 12, 2013

Accepted: December 21, 2013

Correspondence to: Srđan Pavlović, MSc Faculty of Sport and Physical Education Patriotske lige 41 71000 Sarajevo Bosnia and Herzegovina Phone: 0038765646163 E-mail: srdjanpavlovic1984@hotmail.com 